Georgetown University, Washington, DC, USA.

${ }^{6}$ Department of Emergency Medicine, Columbia University Irving Medical Center, New York, NY, USA.

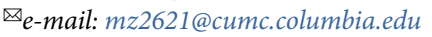

Published online: 19 April 2021

https://doi.org/10.1038/s41591-021-01328-3

References

1. UNHCR. https://www.unhcr.org/refugee-statistics/ (accessed 23 February 2021)

2. Collins, K. \& Holder, J. https://www.nytimes.com/interactive/ 2021/03/31/world/global-vaccine-supply-inequity.html The New York Times (31 March 2021).

3. Phelan, A. L., Eccleston-Turner, M., Rourke, M., Maleche, A. \& Wang, C. Lancet 396, 800-802 (2020)

4. Berkley, S. Gavi, the Vaccine Alliance https://www.gavi.org/ vaccineswork/covax-explained (2020).

5. Figueroa, J. P. et al. Lancet 397, 562-564 (2021).

6. The Economist Intelligence Unit. The Economist https://www.eiu. com/n/85-poor-countries-will-not-have-access-to-coronavirusvaccines/ (27 January 2021)

7. The New Humanitarian https://www.thenewhumanitarian.org/ maps-and-graphics/2021/coronavirus-humanitarian-updatemap-data-vaccine-aid-response (2021).

8. The International Federation of Red Cross and Red Crescent Societies. https://media.ifrc.org/ifrc/document/least-protectedaffected-migrants-refugees-facing-extraordinary-risks-covid-19pandemic/ (10 September 2020).

9. Nair, S. Refugees International https://www.refugeesinternational. org/reports/2020/12/29/vaccine-authorization-is-just-thebeginning-of-the-journey-to-protecting-displaced-populationsfrom-covid-19 (29 December 2020).
10. Rohan, H. \& McKay, G. Nat. Immunol. 21, 591-594 (2020).

11. Nachega, J. B., Mbala-Kingebeni, P., Otshudiema, J., Zumla, A. \& Tam-Fum, J.-J. M. Lancet Glob. Health 8, e991-e992 (2020).

12. The Global Fund. https://www.theglobalfund.org/en/covid-19/ news/2020-06-17-global-fund-survey-majority-of-hiv-tb-andmalaria-programs-face-disruptions-as-a-result-of-covid-19/ (17 June 2020).

13. Lam, E., McCarthy, A. \& Brennan, M. Hum. Vaccin. Immunother 11, 2627-2636 (2015).

14. Burchett, H. E. D. et al. Vaccine 32, 6505-6512 (2014).

15. Romero, S., Harmon, A., Tompkins, L. \& del Rio, G.M.N The New York Times https://www.nytimes.com/2021/02/04/us/ covid-vaccines-crossing-states.html (4 February 2021).

16. Human Rights Watch. https://www.hrw.org/news/2021/ 01/28/ lebanon-gaps-remain-vaccine-program-planning (28 January 2021).

17. Human Rights Watch. https://www.hrw.org/news/2021/02/02/ syria-covid-19-vaccine-access-should-be-expanded-fair (2021).

18. Lieberman, A. Devex https://www.devex.com/news/

humanitarians-plan-for-covid-19-vaccinations-in-conflictzones-98971 (25 January 2021).

19. Parkin Daniels, J. The Guardian https://www.theguardian.com/ global-development/2020/dec/22/colombia-coronavirusvaccine-migrants-venezuela-ivan-duque (22 December 2020).

20. Welsh, T. Devex https://www.devex.com/news/in-brief-legalstatus-for-venezuelans-in-colombia-to-improve-vaccineaccess-99118 (9 February 2021).

21. Nnadi, C. et al. J. Infect. Dis. 216, S368-S372 (2017).

22. de Quadros, C. Sci. Am. https://www.scientificamerican.com/ article/victories-and-challenges-in-the-war-against-polio/ (2013).

23. Toppenberg-Pejcic, D. et al. Health Commun. 34, 437-455 (2019).

24. Edwards, J.K. et al. MEASURE Evaluation https://www measureevaluation.org/resources/publications/tr-20-412 (2020).

25. Camlin, C.S., Cassels, S. \& Seeley, J. J. Int. AIDS Soc. https://doi. org/10.1002/jia2.25136 (2018).

\section{Acknowledgements}

We thank S. Guyer and K. McCann for research and editorial support. The authors of this Comment are members of a research consortium led by Columbia University's Program on Forced Migration and Health, with the American University of Beirut, Brandeis University, Georgetown University and Universidad de los Andes. The consortium is conducting a two-year research project that aims to provide evidence and guidance to strengthen health systems to address the needs of displaced and host populations in contexts of protracted displacement. The program is funded by UK aid through the Foreign, Commonwealth and Development Office (FCDO). It is managed by the World Bank Group (WBG) and was established in partnership with the United Nations High Commissioner for Refugees (UNHCR). This work does not necessarily reflect the views of UK Aid, the WBG or UNHCR.

\section{Author contributions}

All authors jointly conceived of and conceptualized the commentary; M.Z. led the design and development of the manuscript; M.Z., L.S.L. and M.N.A conducted background research; M.Z. and L.S.L. drafted and revised the manuscript; and all authors reviewed the manuscript and provided several rounds of critical feedback.

\section{Competing interests}

The authors declare no competing interests.

\section{Additional information}

Supplementary information The online version contains supplementary material available at https://doi. org/10.1038/s41591-021-01328-3.

\title{
Sustained behavior change is key to preventing and tackling future pandemics
}

Investment in research and programs to discover and apply the principles that underpin sustained behavior change is needed to address the continuing threat from COVID-19 and future pandemics and will require collaboration among behavioral, social, biomedical, public-health and clinical scientists.

\section{Susan Michie and Robert West}

1 uman behavior was instrumental in causing COVID-19, and changing it has been vital to tackling this pandemic. The countries that have done best in mitigating COVID-19's harms to health and to their economies have rapidly and successfully persuaded their populations to enact large-scale behavior change. Some of these interventions have been highly effective, others have been less so, and some have produced substantial social and financial harm. In particular, national 'lockdowns' have been effective in keeping people from interacting, to reduce the spread of disease ${ }^{1}$, but they have been very damaging to people's lives and to national economies. Therefore, lockdowns should ideally be used only to bring transmission levels low enough to be controllable by other policies. These policies include adequate 'find, test, trace, isolate and support' systems ${ }^{2}$; border controls and quarantine to prevent reseeding of infections; the creation of safe working, domestic and transport spaces; and the promotion of personal protective behaviors such as the use of face coverings ${ }^{3}$.

Capability, opportunity and motivation Large-scale, sustained behavior change is needed to reduce the risk of, and to prepare for, future pandemics. ${ }^{4}$ The COVID-19 pandemic has shown that populations will adopt at least some of the required behaviors under certain conditions ${ }^{5}$. However, adoption has been variable across countries, over time and across social groups ${ }^{5}$.

Achieving sustained behavior change requires a sound understanding by policymakers and intervention designers of what underpins the behaviors concerned. For example, what does it take in all cultures to ensure that, where appropriate, people keep safe physical distances from each other, wear face coverings masks and disinfect their hands? What is needed to ensure that adequate ventilation is provided in enclosed spaces, and that people in high-risk settings use personal protective equipment effectively?

We provide here important behavioral targets for the prevention and mitigation of 
Table 1 | Behaviors needed to minimize pandemic harm, and stakeholders responsible for them

\begin{tabular}{|c|c|c|}
\hline Goal & Behavioral targets & Whose behaviors \\
\hline $\begin{array}{l}\text { Reduce } \\
\text { opportunities } \\
\text { for zoonotic } \\
\text { infections }\end{array}$ & $\begin{array}{l}\text { - The capture, breeding, storage and sale of } \\
\text { animals } \\
\text { - The preservation of ecosystems in which } \\
\text { host and reservoir animals live }\end{array}$ & $\begin{array}{l}\text { Policymakers, traders, business } \\
\text { leaders, consumers, general public }\end{array}$ \\
\hline $\begin{array}{l}\text { Prevent initial } \\
\text { spread of } \\
\text { infection }\end{array}$ & $\begin{array}{l}\text { - Early detection, local isolation and } \\
\text { quarantine } \\
\text { - Global early-warning systems for } \\
\text { pandemics }\end{array}$ & $\begin{array}{l}\text { Policymakers, public officials, health } \\
\text { professionals, general public }\end{array}$ \\
\hline $\begin{array}{l}\text { Prevent } \\
\text { spread within } \\
\text { communities }\end{array}$ & $\begin{array}{l}\text { - Case finding, testing, supported isolation } \\
\text { and quarantine } \\
\text { - Social distancing, reducing contact, } \\
\text { disinfection and mask-wearing }\end{array}$ & $\begin{array}{l}\text { Policymakers, health professionals, } \\
\text { key workers, enforcement officers, } \\
\text { general public }\end{array}$ \\
\hline $\begin{array}{l}\text { Prevent spread } \\
\text { between } \\
\text { communities }\end{array}$ & $\begin{array}{l}\text { - Case finding, testing, supported isolation } \\
\text { and quarantine } \\
\text { - Travel and border controls }\end{array}$ & $\begin{array}{l}\text { Policymakers, border officials, } \\
\text { health professionals, travelers, } \\
\text { enforcement officers }\end{array}$ \\
\hline $\begin{array}{l}\text { Build resilient } \\
\text { public-health } \\
\text { systems and } \\
\text { health and care } \\
\text { services }\end{array}$ & $\begin{array}{l}\text { - Adequate resourcing of public health and } \\
\text { health and care services } \\
\text { - The creation and flexible deployment of } \\
\text { surge capacity, and protection of staff }\end{array}$ & Policymakers, health professionals \\
\hline $\begin{array}{l}\text { Minimize } \\
\text { exacerbation of } \\
\text { inequalities }\end{array}$ & $\begin{array}{l}\text { - Engagement of communities in } \\
\text { co-producing policies and interventions } \\
\text { - Tailoring of policies and interventions to } \\
\text { the needs and circumstances of individual } \\
\text { people and groups in society }\end{array}$ & $\begin{array}{l}\text { Policymakers, community } \\
\text { representatives, health professionals, } \\
\text { enforcement officers }\end{array}$ \\
\hline
\end{tabular}

pandemics such as COVID-19 (Table 1). The behaviors vary in what is needed to enact them and the contextual influences on them.

A simple, comprehensive way of understanding behavior is through the 'capability-opportunity-motivationbehavior' (COM-B) model ${ }^{6,7}$ (Fig. 1). This model takes as its premise that for any behavior to occur, people must have

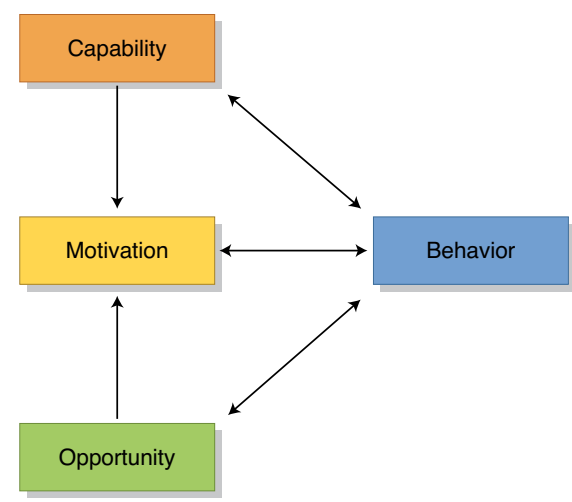

Fig. 1 | The COM-B model of behavior. Capability, opportunity and motivation are all essential for any behavior to occur. Capability and opportunity influence motivation. Behavior feeds back to influence capability, opportunity and motivation. the following: the relevant physical and psychological capabilities; the opportunity; and greater motivation to perform that behavior than anything else they could be doing at the time. Capability and opportunity feed into motivation, so that having greater capability and opportunity can increase motivation (Fig. 1). Behavior then feeds back, and so changing behavior can, in turn, influence capability, opportunity and/or motivation. Thus, behavior is part of an evolving and interacting system. Creating sustained behavior change requires changes to capability, opportunity and motivation that are mutually reinforcing.

Physical capabilities include strength, stamina, and physical and psychomotor skills, whereas psychological capabilities include knowledge, resilience, and mental skills. Motivation comprises both reflective processes, such as self-conscious decision-making, and automatic processes that involve emotions and habits. Opportunity involves having the resources, time and physical space to enact a behavior. It also involves having social structures, norms and cues that make the behavior possible or promote it. The World Health Organization has used the COM-B model to make recommendations for improving adherence

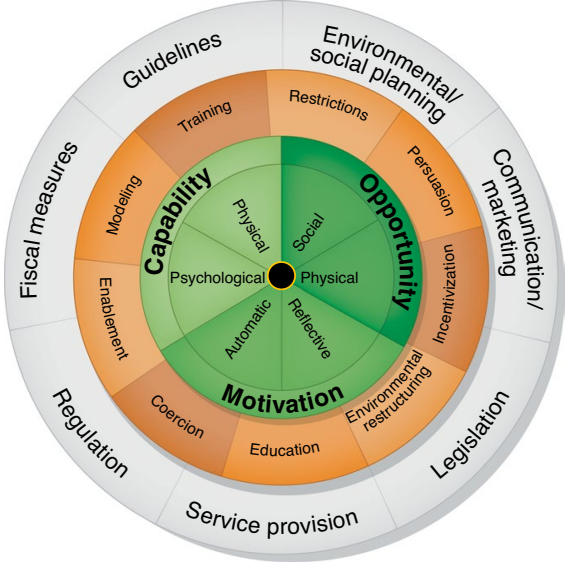

Fig. 2 | The behavior change wheel framework for designing interventions. The layers in the wheel are not intended to line up with each other. Two publications ${ }^{7,14}$ have provided tables showing how a COM-B analysis points to intervention types and policy options most likely to be effective in a given context.

to rules and guidance on behaviors that are protective against COVID-19 ${ }^{8}$.

\section{Requirements for behavior change}

The development of effective interventions requires an understanding of what changes in capability, motivation or opportunity, or their combination, will drive behavior change. Getting the balance wrong can be disastrous. For example, in 2020, the UK government largely failed in its attempts to get people with COVID-19 to self-isolate when needed, in part because it did not heed this lesson. Survey data showed that fewer than 50\% of people with COVID-19 symptoms reported staying at home for the required isolation period ${ }^{9}$. Failure to self-isolate appeared to be driven largely by financial need or domestic or caring responsibilities-i.e., a lack of opportunity 9 . People on low incomes were just as motivated to self-isolate when needed as were those with more financial resources, but did so less ${ }^{10}$. Those who found it easiest to isolate were those who could work from large homes and had the funds to order in meals and other services. Adequate financial and practical support should have been a key part of the solution, and it has been a cornerstone of effective pandemic control in many countries, with up to $100 \%$ of lost wages being reimbursed, and with the provision of free alternative accommodation and daily visits. In the USA, introduction in some jurisdictions of emergency statutory entitlement to sick leave for people with symptoms or who had to quarantine was found to be effective in reducing cases ${ }^{11}$. 


\begin{tabular}{|c|c|}
\hline Target & Examples of strategies \\
\hline $\begin{array}{l}\text { Change } \\
\text { capabilities }\end{array}$ & $\begin{array}{l}\text { - Build pandemic prevention and mitigation into mainstream educational programs } \\
\text { at all levels } \\
\text { - Create and maintain accessible educational resources tailored to the needs of all } \\
\text { social groups }\end{array}$ \\
\hline $\begin{array}{l}\text { Change } \\
\text { opportunities }\end{array}$ & $\begin{array}{l}\text { - Create environments at home, at work and for travel that allow social distancing } \\
\text { when required } \\
\text { - Develop strong social norms around infection-mitigation behaviors }\end{array}$ \\
\hline $\begin{array}{l}\text { Change } \\
\text { motivations }\end{array}$ & $\begin{array}{l}\text { - Foster new identities and values around pandemic prevention and mitigation } \\
\text { - Develop habits and routines that are protective to self and others }\end{array}$ \\
\hline
\end{tabular}

The UK government appeared to have erroneously assumed that the main reason people did not isolate was a lack of motivation, whereas it was instead a lack of opportunity. It threatened a fine of $£ 10,000$ for failure to comply with isolation mandates. An evaluation of free, mass testing in the city of Liverpool found that the take up of diagnostic tests among disadvantaged groups was as low as $4 \%$ in some areas ${ }^{12}$, and a $£ 36$ billion 'test, trace and isolate system' was estimated to have reached as little as 3\% of contacts of people who had tested positive for COVID-19 13 . It seems that the threat of a large monetary fine did have a motivational influence, but it was opposite to that intended, with the best way of avoiding a fine being to avoid a test.

\section{The behavior change wheel}

The UK case study described above illustrates the fact that for mass behavioral changes to achieve their intended outcome, systematic approaches need to move from an understanding of behavior in its context to identifying interventions and policies that can change the behavior. One such framework is the behavior change wheel, developed through the integration of 19 frameworks identified in a literature review $^{7,14,15}$ (Fig. 2). This wheel can be used to link the COM-B model with nine possible types of intervention and seven policy options for implementation. Intervention designers can use the wheel to identify the intervention types most likely to achieve the desired change and can then choose the most appropriate mixture of implementation options, given whatever constraints may be operating.

Use of the behavior change wheel framework can be illustrated by the challenge of getting healthcare staff to adhere to infection prevention and control guidelines. A published study identified a range of interventions that could be effective $^{16}$, but it was important to go further and consider the capability, opportunity and motivation issues that needed to be addressed in a given context. First, in terms of capability, there was the nature of the guidelines, how they were communicated and what training was needed for this. Second, in the context of opportunity, it was essential to consider the physical spaces the staff worked in and the support they received from managers ${ }^{16}$. Third, for motivation, it was important that staff had trust in their personal protective equipment and that it was comfortable to use as required. Finally, to fully address the capability, opportunity and motivational issues, it was essential to include all staff, including support staff, in the process of intervention development and implementation ${ }^{15}$. The findings of this study further illustrated the need to treat all the actors and behaviors in a given scenario as part of an interconnected system, and pointed to workplace culture as an important influence, specifically managerial and peer support, social-norms solidarity and a focus on safety rather than complacency ${ }^{16}$.

\section{Leadership, trust and solidarity}

When it comes to motivation to adhere to stringent pandemic control regulations, variation in practices across different countries has highlighted the importance of good leadership fostering public trust in government and experts, and a sense of solidarity ${ }^{17}$. Trust derives from people seeing authorities as part of and serving the community ${ }^{18}$, and this in turn derives from these authorities treating the public as a respected partner rather than as a problem ${ }^{19}$.

The importance of fostering trust and solidarity has informed much of the advice provided by behavioral scientists participating in the UK government's This group has urged the government to understand the diversity of communities Scientific Advisory Group for Emergencies. that make up the UK population, and to engage with, consult, listen to and learn from them. In addition, the government was urged to support and enable the population to adhere; to avoid blame and punishment; to recognize, reward and celebrate achievements, often in challenging circumstances; and to communicate clearly, consistently and concisely, in line with evidence. Finally, the government was advised to be transparent, honest and open in written and verbal communication; to engender trust; and to avoid socially divisive language, policies and behavior.

Sustaining behavior change involves taking these principles and applying them to create a mutually reinforcing system in which capability, opportunity and motivation support each other (Table 2). For example, sustained improvements in knowledge will need education about viral transmission and its prevention to be built into educational programs at all levels. Improved opportunity will require structural changes to inhabited spaces to make it easier to achieve social distancing when required. Sustained changes to motivation will involve the development of social identities that place greater value on behaviors that mitigate infection risk and the development of habits and routines that embed these behaviors into everyday life.

The principles noted above are generic. Detailed scientific investigation is needed to develop and successfully apply them to create interventions suited to different scenarios. Such interventions have been called 'behavioral, environmental, social and systems interventions' (BESSIs) ${ }^{4}$. Despite the importance of these kinds of intervention, research investment in all BESSIs collectively has been estimated to be less than $4 \%$ of the $\$ 3.3$ billion in global spending on COVID-19 research ${ }^{20}$. In a comparison of BESSI versus pharmacological trials, the contrast is stark: as of December 2020, there were 1,725 registered pharmacological trials and 213 conducted pharmacological trials, but only 11 registered BESSI trials and 3 conducted BESSI trials ${ }^{21}$.

\section{Tackling inequalities}

An important lesson from the COVID-19 pandemic is that no person or community or country can protect themselves or itself on their or its own: humans are all interconnected, and solutions must be global. Building pandemic-resilient societies for the future must include changing population-wide behaviors, as well as reducing inequalities. Embedding behaviors into societies requires changes to physical and social environments, such as fostering safe workplaces and norms around hygiene 
behaviors. These need to be underpinned by community activation, organization regulation and national legislation.

Societies that are already unequal have been made more so by the COVID-19 pandemic, with the virus spreading most aggressively in overcrowded, multigenerational housing and poorly regulated workplaces. Furthermore, those with pre-existing health problems and those from specific ethnic backgrounds, both linked to poverty, were hit harder by the virus. Structural racism in many countries meant that those who were already more vulnerable were made doubly so due to low incomes and poor working conditions. On top of these increased inequalities came government policies that exacerbated inequalities further in many countries. In the UK, workers on regular salaries were more financially protected than those working in the precarious economy, and mortgage-holders were better protected than renters.

Testing for the virus, as well as medicines and vaccines, will continue to be vital to the strategy for tackling COVID-19 and future pandemics. But a substantial rebalancing of funding on research and programs needed to embed behavioral changes across society and address inequality will also be critical in the long run.

\section{Susan Michie (D) $1 \times$ and Robert West (D) $2 \bowtie$ ${ }^{1}$ Centre for Behaviour Change, University College London, London, UK. ${ }^{2}$ Department of Behavioural Science and Health, Institute of Epidemiology and Healthcare, University College London, London, UK.

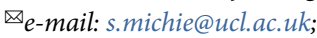 \\ robertwest100@gmail.com}

Published online: 10 May 2021

https://doi.org/10.1038/s41591-021-01345-2

\section{References}

1. Flaxman, S. et al. Nature 584, 257-261 (2020).

2. Rajan, S., Cylus, J. \& McKee, M. Eurohealth 26, 34-39 (2020).

3. West, R., Michie, S., Rubin, G. J. \& Amlôt, R. Nature Human Behaviour 4, 451-459 (2020).

4. Michie, S. \& West, R. Br. Med. J. 370, m2982 (2020).

5. Becher, M., Stegmueller, D., Brouard, S. \& Kerrouche, E. Preprint at https://doi.org/10.2139/ssrn.3652543 (2020).

6. West, R. \& Michie, S. Qeios https://doi.org/10.32388/WW04E6.2 (2020).

7. Michie, S., van Stralen, M. M. \& West, R. Implement. Sci. 6 42 (2011).

8. World Health Organization. Regional Office for Europe. https://apps.who.int/iris/handle/10665/337574 (November 2020).

Smith, L. E. et al. Brit. Med. J. 372, n608 (2021)

10. Atchison, C. J. et al. BMJ Open 11, e043577 (2021).

11. Pichler, S., Wen, K. \& Ziebarth, N. R. Health Aff. 39, 2197-2204 (2020)
12. University of Liverpool. https://www.liverpool.ac.uk/research/ news/articles/covid-19-liverpool-community-testing-pilotinterim-findings-published/ (23 December 2020)

13. Wood, P. CityAM https://www.cityam.com/dido-hardingslammed-for-three-per-cent-test-and-trace-success-rate (10 November 2020)

14. West, R., Michie, S., Chadwick, P., Atkins, L. \& Lorencatto, F. Public Health England https://assets.publishing.service.gov.uk government/uploads/system/uploads/attachment_data/file/ 933328/UFG_National_Guide_v04.00_1__1_.pdf (2020).

15. Michie, S., Atkins, L. \& West, R. The Behaviour Change Wheel: A Guide To Designing Interventions (Silverback Publishing, 2014).

16. Houghton, C. et al. Cochrane Database Syst. Rev. https://doi. org/10.1002/14651858.CD013582 (2020).

17. Wright, L., Steptoe, A. \& Fancourt, D. Preprint at medRxiv https:// doi.org/10.1101/2020.10.19.20215376 (2020).

18. Brewer, M.B. in Rationality and Social Responsibility: Essays in Honor of Robyn Mason Dawes 215-232 (Psychology Press, 2008).

19. Tyler, T. R. \& Blader, S. L. Pers. Soc. Psychol. Rev. 7 , 349-361 (2003).

20. Head, M. G. et al. Lancet Glob. Health 8, e1295-e1304 (2020). 21. BESSI. https://www.bessi-collab.net (accessed 23 April 2021).

\section{Author contributions}

S.M. and R.W. contributed to the concept for this

Comment, and to the initial drafting and to revisions.

\section{Competing interests}

S.M. and R.W. are unpaid directors of the Unlocking Behavior Change community interest company, and are participants in the Independent Scientific Pandemic Insights Group on Behaviours of the UK Scientific

Advisory Group for Emergencies, and in the Independent Scientific Advisory Group for Emergencies.

\title{
First-generation physician-scientists are under-represented and need better support
}

\author{
First-generation students, whose parents do not have baccalaureate degrees, are less likely to apply to MD-PhD \\ programs than to MD programs, which has led to a worrying lack of diversity among physician-scientists.
}

\section{Briana Christophers, Briana Macedo, Edwin Nieblas-Bedolla, Mollie Marr, Olaf S. Andersen and Catharine Boothroyd}

P hysician-scientists occupy a unique and important space that bridges scientific research and medical practice, and many have expressed concern that physician-scientists are an endangered species, with a dwindling pool of interested future researchers ${ }^{1-4}$. Indeed, the number of MD-PhD applicants in the USA has remained stagnant from 2012, when there were 1,853 applicants, to 2020 , when there were 1,825 . Meanwhile, applications to medical school have steadily increased during the same time period, from 45,266 to 53,030 (refs. ${ }^{5,6}$ ). Is this because the traditional pool of applicants-those who have adequate advising and probably do not come from minority identities-has reached saturation? If so, there is a pressing need to recruit students who do not fit the traditional mold into the physician-scientist career path.

People who identify as the first in their family to receive a baccalaureate degreealso known as 'first-generation' studentsremain under-represented in $\mathrm{MD}-\mathrm{PhD}$ programs in the USA. The experience of first-generation physician-scientists in training has been excluded from conversations about diversity and inclusion, since first-generation status often intersects with other under-represented identities. The needs and barriers faced by first-generation $\mathrm{MD}-\mathrm{PhD}$ applicants and trainees probably overlap those faced by first-generation undergraduate, medical and graduate students, but due to a lack of research, some specific needs and barriers are unknown and will require future study.

Given that first-generation MD-PhD students come from a background currently under-represented in medicine, they may be more likely to focus on important but under-investigated problems pertaining to the nation's health. For example, it was not until the US National Institutes of Health had its first female director, in the early 1990s, that it was mandated that women be included in clinical trials for diseases that affected more than just men ${ }^{7}$. Similarly, a 2018 study showed a 19\% decrease in cardiac mortality in Black men when they were 